\title{
Supporting Factors and Consequences of Child Marriage
}

\author{
Nilla S. D. Iustitiani \\ Pusat Kajian Pembangunan Masyarakat (PKPM) \\ Atma Jaya Catholic University of Indonesia
}

\author{
Clara R. P. Ajisuksmo \\ Faculty of Psychology \\ Atma Jaya Catholic University of Indonesia
}

\begin{abstract}
This study aims to give an overview of the causes and consequences of child marriage by qualitative research using in-depth interview techniques. Participants were eight girls who married during their childhood and live in Java, Indonesia. Interviews were analyzed by using content analysis techniques. The results show that underlying factors causing child marriage, include the following: (1) unwanted pregnancy; (2) the influence of parents and the surrounding environment for fear of slander and unwanted things; (3) education; and (4) economy. The consequences of child marriage include: (1) dicontinuation of education; (2) economic instability; (3) violation of law, age falsification, unregistered marriage, difficulties in obtaining birth certificates; (4) deprivation of children's liberty and autonomy; (5) psychological problems; (6) violence; and (7) health problems especially in girls.
\end{abstract}

Keywords: early marriage, child marriage, causes, impact, child

Penelitian ini bertujuan memperoleh gambaran mengenai faktor pendukung dan dampak penikahan pada usia anak. Penelitian dengan pendekatan kualitatif ini menggunakan teknik wawancara mendalam untuk pengambilan data. Partisipan adalah delapan orang perempuan yang menikah pada usia anak dan tinggal di wilayah Jawa, Indonesia. Teknik analisis yang digunakan adalah teknik analisis isi. Hasil menunjukkan bahwa faktor yang menjadi penyebab terjadinya pernikahan pada usia anak antara lain: (1) kehamilan yang tidak diinginkan; (2) pengaruh orang tua dan lingkungan sekitar yang takut terjadi fitnah dan hal-hal yang tidak diinginkan; (3) pendidikan; dan (4) ekonomi. Dampak dari pernikahan pada usia anak, antara lain: (1) terputusnya pendidikan; (2) ketidakstabilan ekonomi; (3) pelanggaran hukum, baik pemalsuan usia, tidak dicatatkannya pernikahan tersebut, hingga anak hasil pernikahan tersebut tidak memiliki akta kelahiran; (4) terampasnya kebebasan dan otonomi anak; (5) permasalahan psikologis; (6) kekerasan; dan (7) masalah kesehatan khususnya pada anak perempuan.

Kata kunci: pernikahan dini, pernikahan pada usia anak, penyebab, dampak, anak

The practices of child marriage in Indonesia still happens. Detiknews.com mentioned in the area of Banjarnegara in 2017 was recorded as many as $30 \%$ of marriage at the child age (Hartono, 2017). The Ministry of Women Empowerment and Child Protection states that Indonesia is currently in child marriage emergency situation (Juniman, 2017).

In Indonesia, the rules governing marriage are contained in Law No. 1 of 1974 on Marriage. In Article 7 paragraph (1), the Act mentions the minimum age of marriage for couples, which is 19 years for men and 16 years for women. In paragraph (2) it is added that whenever a deviation to paragraph (1) occurs, the couple should obtain dispensation from the court

Correspondence concerning this article should be addressed to Nilla Sari Dewi Iustitiani, PKPM Unika Atma Jaya Jalan Jend. Sudirman No. 51, Jakarta. E-mail: nillasari.dewi@atmajaya.ac.id or from other officials appointed by parents of husband and wife. In other words, if one or both of the individuals has not reached the minimum age limit, then the marriage can still be legalised by obtaining permission from both parents as represented by the court or appointed officials.

This situation is of course in contrary to the Convention on the Rights of the Child (CRC) that was ratified by Indonesia as Law No. 23 of 2002 on Child Protection and Law No. 35 of 2014 on the Amendment of Child Protection Act. Article 26 paragraph 1c of Law no. 35 Year 2014 on the Amendment of Child Protection states that parents are obliged and responsible for preventing child marriages. However, the article is still unclear about the prohibition of age of child marriage and what sanctions should be given in the event of child marriage. 
According to the International Planned Parenthood Federation (2006), child marriage is defined as any marriage of individuals under the age of 18 , where the female partner is physically, physiologically and psychologically not yet ready to assume responsebility from her marriage and to give birth to a child. Surely the age limit of marriage would vary according to each country. UNICEF as one of the UN agencies engaged in the issue of child protection, stipulates that the minimum age of marriage is 18 years (Umemoto, 2001; UNICEF, 2005). The minimum age limit is set by considering the Convention on the Rights of the Child which states that those who are not yet 18 are still considered and categorized as children (UNICEF, 2005). Therefore, should a marriage occur among those below the minimum age, then it is considered as child marriage and is a violation of child protection.

Indonesia today still refers to Law no $1 / 1974$ on marriage as the basis for all marital unions. In other words, the state still permits child marriages and considers it legal within Indonesia. Other evidence that suggests Indonesia still allows child marriage practices is the fact that even though the United Nations had adopted the resolution to abolish child marriage in 1976, Indonesia still had not taken steps regarding the prevention and elimination of child marriages until 2017.

The 2015 National Socio-Economic Survey ( $\mathrm{Su}$ senas) data (BPS, 2016) indicates a decrease in the prevalence of child marriage from $24 \%$ in 2014 to $23 \%$ in 2015 . By 2015, the prevalence of child marriages at in rural areas $(27.11 \%)$ is one third higher than those in urban areas (17.09\%). Some areas in Indonesia with a high prevalence of child marriage are West Sulawesi (34.22\%), South Kalimantan (33.68\%), Central Kalimantan (33.56\%), West Kalimantan (32. $21 \%$ ) and Central Sulawesi (31.91\%) (CPM, 2016). A common characteristics of these five provinces are that they predominantly rural areas. This suggests that prevalence of child marriage is higher in rural areas compared to urban areas. Despite the decrease in prevalence, the data also suggests that child marriage is widespread in Indonesia.

Child marriage may be considered as a violation of the rights of the child due to the fact that by getting married children will lose and be deprived of certain rights (BPS, 2016), such as the rights to grow, the rights to education, the rights to freedom, the rights to health, and the rights to childcare. In addition to these violation of rights, child marriage may also be considered as a form of violence against child- ren. According to WHO (1990), violence is any form of action that includes physical, emotional, sexual abuse, neglect and exploitation committed within the context of a relationship that contains responsibility, power or trust, will all result in actual and potential losses of their health status, their ability to survive, and personal development and self-esteem. Based on this definition, child marriage can be considered as a form of violence against children because it brings disadvantage to their health status, personal development and self-esteem.

Naveed and Butt (2015) state that more child marriages were done under the pretext of poverty, gender inequality, and illiteracy. They furthermore explained that child marriages have impact on physical, psychological, social, and economic aspects. Girls are deprived from education, and in general often experience physical, emotional and sexual abuse. Qibtiyah (2014) found that economic and cultural factors have no direct influence towards the occurrence of child marriages, but rather education and place of residence have more influence. This is in accordance with Desiyanti's (2015) findings that parents and children's education level as well as family communication are factors associated with the occurrence of child marriages. The role of parents in family communication is the most dominant factor of child marriages.

Candraningrum, Dhewy, and Pratiwi (2016) argue that poverty and poor access to education, the rise of religious fundamentalism and poor access to sexual health rights of reproductive health are also considered to be factors causing child marriage. The PSKK UGM and Plan International report (2011) explains that there are five causes of child marriage, namely: (1) sexual behavior and unwanted pregnancy; (2) tradition or culture; (3) low knowledge related to reproductive health or sexuality and low education level of parents; (4) socio-economic and geographical factors; and (5) weak law enforcement.

Child marriages will certainly have a certain impact on children, and this should be taken into account at all levels to prevent further occurrence of child marriages. The PSKK UGM and Plan International (2011) reports that there are both positive and negative some impacts experienced by these children. The positive impact of child marriage is leading a happy, married life because the children make their own decision to marry, although there might be a possibility that the study participants would say so because they are still in the "honeymoon" period and are still relatively young. Another positive impact is 
Table 1

Guideline for Interview

\begin{tabular}{|c|c|c|}
\hline No & Topic & Questions \\
\hline 1 & Demografic Data & $\begin{array}{l}\text { - How old are you and your partner? } \\
\text { - How old you and your partner when first marriage? } \\
\text { - What your marriage status now? } \\
\text { Probe: marrital status, number of children, live with whom }\end{array}$ \\
\hline 2 & Supporting Factors & $\begin{array}{l}\text { - First, can you describe when you committed to first marriage? } \\
\text { Probe: reason, family' responses, the legal marriage process } \\
\text { - What your education status when first marriage? } \\
\text { Probe: dropout before or after marriage, school' response, school friends response, } \\
\text { what the reason of dropout before marriage } \\
\text { - Have you having sex before marriage? } \\
\text { Probe: are you marriage because unwanted pregnan, sexual education } \\
\text { - How you relation with your family after marriage? } \\
\text { Probe: acceptance from parents and parents in law, relying with family } \\
\text { - How community perspective when they know you marriage? } \\
\text { Probe: child marriage stigma } \\
\text { - Are you know the reason why someone marriage in the child age? } \\
\text { Probe: economy factors, social factors, culture factors, media }\end{array}$ \\
\hline 3 & Consequences & $\begin{array}{l}\text { - How your marriage life? } \\
\text { Probe: before and after marriage, up and down during marriage } \\
\text { - Have you experience violence? } \\
\text { Probe: kind of violence, your response, family response } \\
\text { - How your economy status after being marriage? } \\
\text { - Is there any psychological diffence before and after marriage? } \\
\text { - Have you experience physical problems after marriage? } \\
\text { - Probe: physical difference before and after marriage, pregnancy problems } \\
\text { - Any other consequence that you experience after marriage? }\end{array}$ \\
\hline
\end{tabular}

the improvement in family economic status, although in some areas it is also found that the family economic status may decline because of the increasing household needs and still being dependent on their parents. Negative impacts of child marriage at the age of the child include children dropping out of school, conflicts due to forced marriage and psychosocial changes, domestic violence, and complications during pregnancy. Rodgers (2012) states that ending child marriage practices can become obstacles in reducing poverty and hunger, achieving basic education, promoting gender equality, and improving maternal and child health.

The number of factors causing child marriages make prevention efforts more complicated. The limited concern of the government on child marriage practices makes prevention efforts of child marriages more difficult. According to Hanafi (2011), the absence of government concern is reflected in the absence of accurate data related to the child marriage practices as reported by government institutions and agencies such as the Central Bureau of Statistics (BPS), the Office of Religious Affairs (KUA), and the Religious Court (PA). He also added that the absence of such data is further exacerbated by ignorance and unwillingness of the community in the study sites to register their marriages. The lack of accurate data concerning child marriage may likely cause government's ignorance, where the government considers child marriage practices as nonexistent or very low.

The exposure of the child marriage is very complex. Supporting factors of child marriage can also be the consequences of child marriage. This research wants to expose about the supporting factors and the consequences of child marriage is seen from the perspective of the child rights. Through this research, is expected to give an idea that does not satisfy the child rights can have a consequences on child marriage and also give an idea of the consequences of the child marriage against the child rights. 


\section{Methods}

\section{Methodological Approach}

Data is collected by using qualitative methods, that is, by conducting in-depth interviews to subjects involved in child marriage. The interview was conducted in a single meeting, and very open to doing a follow-up interview if the data obtained is still not able to answer the research questions. Before starting the interview, the researcher establish the rapport with the participants, so participants can be more open. After felt that participants can already open and the situation is becoming more fluid, then the interview to answer this research was conducted. During the interview process is done using tools audio recording to facilitate the researchers recalled the results of the interviews conducted. Content analysis are then conducted by emphasizing objectivity, systematic analysis, and generalization of the concept.

The type of research is descriptive qualitative. This study only aims to describe the factors that support the occurrence of child marriages and its consequences. The study was conducted in three locations in Java, namely Bekasi, Indramayu, and DKI Jakarta.

\section{Subjects}

Subjects in this study are those who experienced marriage at the young age. Based on the age limit as defined by the Convention on the Rights of the Child (CRC), the participants of this study were under the age of eighteen at the time of marriage. The sampling method used in this study is snowballing method, considering that such participants are rare to find.

Before conducting interviews, the researchers asked the verbal consent. Verbally consent was chosen because it was considered more comfortable almost for most subjects in this study. For the verbal consent, researchers explain the principle of confidentiality and subject also reserves the right to refuse to answer or even to withdraw from the process of the study. Statement concerning willingness and agreement of all recorded in digital form by audio recorders that are owned by the researcher. In addition to requesting the consent of the subjects, the researchers also asked for approval of the representatives of the parents and subject' couple before doing an interview.

\section{Instruments}

This study uses interview guides as a reference for conducting interviews to the subject. The interview guides were developed by researchers focusing on the underlying factors and impacts of marriage at the age of the child. Table 1 is a guideline for interviewer to answer the research question.

\section{Discussion}

\section{Overview of Participants}

There are eight participants, all female. Table 2 shows the general overview of participants.

Table 3 shows the participants' age range between 17 to 21 at time of study. Two of the participants were married at the age of 16-18, whereas one parti-

Table 2

Overview of Participants

\begin{tabular}{|c|c|c|c|c|c|c|c|}
\hline \multirow[b]{2}{*}{ Participant } & \multirow[b]{2}{*}{ Gender } & \multicolumn{2}{|c|}{ Age } & \multicolumn{2}{|r|}{ Place to Stay } & \multirow{2}{*}{$\begin{array}{c}\text { Economy } \\
\text { Status }\end{array}$} & \multirow{2}{*}{$\begin{array}{l}\text { Marital } \\
\text { Status }\end{array}$} \\
\hline & & $\begin{array}{c}\text { At } \\
\text { present }\end{array}$ & $\begin{array}{c}\text { At first } \\
\text { marriage }\end{array}$ & Location & House status & & \\
\hline LI & $\mathrm{F}$ & 19 уо & 15 уо & Indramayu & $\begin{array}{l}\text { Rent house; live with her } \\
\text { husband and children }\end{array}$ & Poor & $\begin{array}{l}\text { Divorce } \\
\text { and } \\
\text { Remarried }\end{array}$ \\
\hline SI & $\mathrm{F}$ & 19 yо & 18 yо & Indramayu & Living with parents & Poor & Divorce \\
\hline NI & $\mathrm{F}$ & 21 yo & 18 yo & Indramayu & Living with parents & Poor & Marriage \\
\hline YJ & $\mathrm{F}$ & 18 yo & 16 уо & $\begin{array}{l}\text { East } \\
\text { Jakarta }\end{array}$ & $\begin{array}{l}\text { Rent house; live with her } \\
\text { husband and children }\end{array}$ & Poor & Marriage \\
\hline $\mathrm{AM}$ & $\mathrm{F}$ & 18 yo & 17 yo & Bekasi & Living with parents & Poor & Marriage \\
\hline DM & $\mathrm{F}$ & 17 yo & 16 уо & Bekasi & Living with parents & Poor & Divorce \\
\hline SM & $\mathrm{F}$ & 15 уо & 13 уо & Bekasi & Living with parents & Poor & Marriage \\
\hline HM & $\mathrm{P}$ & 18 yo & 17 yo & Bekasi & $\begin{array}{c}\text { Rent house; live with her } \\
\text { husband }\end{array}$ & Rich & Marriage \\
\hline
\end{tabular}


Table 3

Participants Age

\begin{tabular}{lcccc}
\hline \multirow{2}{*}{ Age } & \multicolumn{2}{c}{ At present } & \multicolumn{2}{c}{ At marriage } \\
\cline { 2 - 5 } & $n$ & $\%$ & $n$ & $\%$ \\
\hline 14 & 0 & .0 & 1 & 12.5 \\
15 & 0 & .0 & 1 & 12.5 \\
16 & 0 & .0 & 2 & 25.0 \\
17 & 1 & 12.5 & 1 & 12.5 \\
18 & 3 & 37.5 & 2 & 25.0 \\
19 & 2 & 25.0 & 1 & 12.5 \\
20 & 1 & 12.5 & 0 & .0 \\
21 & 1 & 12.5 & 0 & .0 \\
\hline
\end{tabular}

Table 4

Participants' Educational Status

\begin{tabular}{llc}
\hline Educational Level & $n$ & $\%$ \\
\hline Elementary school dropout & 1 & 12.5 \\
Junior high graduate & 1 & 12.5 \\
Junior high dropout & 2 & 25.0 \\
Senior high graduate & 0 & .0 \\
Senior high dropout & 4 & 50.0 \\
\hline
\end{tabular}

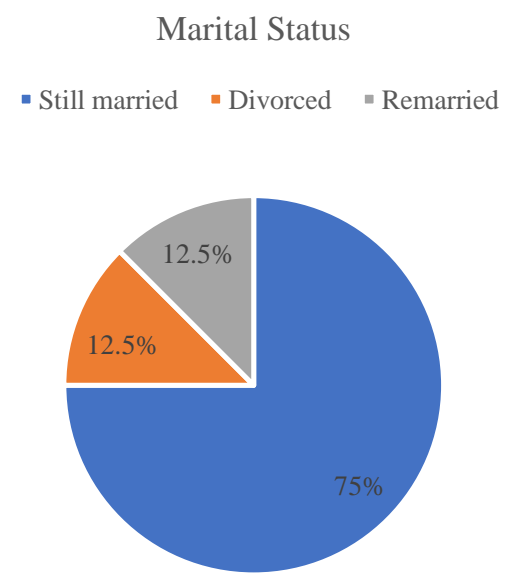

Figure 1. Participants' marital status.

cipant was married at the age of 19. Although this is above the minimum age limit, this participant is included as her husband was considered a child when he married her at the age of 17.

\section{Participants' Educational Status}

Table 4 shows participant's educational status. Most participants dropped out at the junior and senior high school levels. There were four junior high school dropouts $(50.0 \%)$, two junior high school dropouts $(25.0 \%)$, one junior high school graduate who did not continue education $(12.5 \%)$, and one elementary school dropout (12.5\%).

\section{Participants' Marital Status}

Figure 1 shows that $75 \%(n=6)$ of the participants are still married to their spouses, one person $(12.5 \%)$ divorced from her partner, and one $(12.5 \%)$ is divorced and remarried.

Seven of the eight participants were married with a "siri" status, which is officially not recognized by civil registry and is only recognized religiously. One participant was legally married, both according to religious regulations and civil registration. Although at that time of marriage, participants were underage, some of them increased their age to get permission to marry.

\section{Social Economy Status}

From the living status, six of eight participants live separately from their parents, where they live in rent house. The remaining two were still living together with both their parents.

On the basis of the work which is owned by the participant, it is known that there are only two participants who are working as trade of the food, one participant helps her partner to process the catch to sea, while the rest as a housewife. The work of their partner also vary, three partner of participants have a job and a steady income, for example working in one of the Non-Governmental Organization, working in the store daily needs, and factory laborers. Four partner of participants do not have a steady income, because they work as a fisherman. One partner of participant worked as a mechanic in a garage belonging to the families of the participants, but since the divorce her partner then no longer work.

\section{Factor Causing Child Marriage}

There are two factors causing the occurrence of child marriage, mainly educational and social factors. The first factor is the disconnection of access to education, whether formal education or information about reproductive health. Lack of education or knowledge about reproductive health indirectly may affect the occurrence of unwanted pregnancy. The third factor is the feeling "ashamed" of the views and the stigma of the surrounding environment. Another factor is economic issues, because economic conditions cause someone the child does not have access to education. Although there are other factors causing child marriage, namely economic, cultural and religious factors, but these were not found in this study. 
The results show that three of the eight participants had already dropped out of school before they dated their future husband. The reasons for dropping out of school were varied, that is, they could not afford to continue their education, the desire to work and earn a living, and family mobility that required participants to frequently move made them lose interest in schooling. After dropping out, participants spent most of their time helping their parents with housework, including taking care of their siblings.

One of the three participants decided to quit school because she desired to work. However, after she found a job, she did not enjoy working and decided to quit the job. After quitting her job, she spent more time at home helping both parents to do housework. The study also found that the spouses of all participants had dropped out from elementary and junior high school. Unlike other participants who had not been out of school for long, the participants had dropped out of school much longer than the participants. Participants HM and SM said:

"...I wanted to continue, but you know if I keep on going to school, it is expensive. Moving to grade 3 is expensive, so I decided to quit school. Exams are expensive, even after paying, I could just quit." (HM, Bekasi)

"I'm tired of working, so I decided to just get married." (SM, Bekasi)

One possibility is that uncertainty of the future and having to spend most time doing domestic work could be the reasons why participants decide to get married young. Some participants married without considering other matters. Marriage to them was solely based on love towards their partner.

Another thing found related to the education is the participants' ignorance about reproductive health and consequences of child marriage. Ignorance of participants related to reproductive health ultimately led them to be engaged in premarital sex and unwanted pregnancies. Low knowledge of reproductive health made some participants become unaware of their own pregnancy. Unwanted pregnancy could be the main reason why they decided to marry young, as Participants SI and AM mentioned.

"...well, I was already suspicious, then I asked my friend why I have not had my period for 3 months. She told me to get a check up or it could be a disease... but I had no time to check." (SI, Indramayu)

"...at that time I had to make measurements for field work uniform, and the teacher asked me why I was pale... I did not know... She continue ask if I was pregnant... I continued to say I did not know. She hold my stomach, but kept quiet... when I arrived home I told my family." (SI, Indramayu)

"I had my first contact or first date at the age of 17 , I decided to get married because I was afraid of getting pregnant... it was both our decisions." (AM, Bekasi)

Another factor that causes child marriage is more social in matter. There are two things, namely the role of society and also the role of the media. Data indicates that society plays a role in child marriage. Three existing cases indicate that marriages took place because of gossip from the community. The community accused participants being engaged in premarital sex or some were pregnant. This causes parents to ask their children to marry on the grounds of avoiding slander. Participants AM, DM, and HM confessed as follows:

"...my parents told me to choose... to continue school or get married. I told them I'd rather just marry and no longer want to go to school. Why should I go to school and fail, and just embarrass my parents. If I continue school who knows, $\mathrm{i}$ could be like other kids, getting pregnant before marriage. I'm afraid of that... really scared about that. So when I was given the choice, do I want ot go to school, I said no..." (AM, Bekasi)

"...actually it's because of what people say, I pity my parents... well, we were both in love anyway... I actually just wanted to continue dating him but people were gossiping, they said, we've done this and that, that I was pregnant, which in fact I wasn't... so I said, I'd rather just get married." (DM, Bekasi) "...my husband's family told us to get married." (HM, Bekasi)

The media also contributes to the occurrence of child marriages. Participants and their partners were exposed to pornography though social media and the Internet. Out of curiosity many participants become sexually involved with their dating partners. This ultimately led to unwanted pregnancies and as a consequence they were forced to take responsibility by getting married. 


\section{Consequences of Child Marriages}

There are educational, social, economic, legal, physical, and psychological aspects leading to the consequences of child marriages. As a result of child marriage, five out of eight participants had to drop out of school. One participant was even known to quit school after the school found out she was going to get married. Participants SM, LI, and SI said:

"I was married when I was still at school grade 6, after school exams I got married. I've done my exams, I haven't done my practical test.. I got married..." (SM, Bekasi)

"I got married in 3rd grade junior high school. I purposely did not take the entrance test afterwards." (LI, Indramayu)

"...I was in grade 2, secondary school, when I was going to do field work at the vocational high school." (SI, Indramayu)

This was due to participants' feelings of shame and discomfort when the school and their friends found out that AM and HM were going to get married soon. Most participants did not know that there was no prohibition for those married to continue schooling. They even had no information that they can take alternative education packages. Participants were of the opinion that those who were married, especially those who had children, could no longer go to school. Participants AM and HM said:

"...I wanted to... tell my husband so... my husband allowed me, but I think it's not okay if one is married and still goes to school." (AM, Bekasi) "I didn't want to go to school, I was too embarassed." (HM, Bekasi)

"When I was in school I had less things to worry about. But now there are so many burdens. When you're married, that's how it is. When you're in school, when you have no money, you ask your parents. But now, I'm too shy to do that. They will then say, it's your own fault for marrying young, my parents would tease me like that. It's your own fault for getting married. If you went to school you could work." (AM, Bekasi)

Those who were married underage are often times mostly to be vulnerable. As indicated by one participant (LI) who after getting married was physically abused by her husband and psychologically abused by both husband and his family. She receive unplea- sant treatment from her husband by getting beated when he returns home intoxicated, whereas her husband's family often verbally insults her, for example, by accussing her as not being a good woman. Even after childbirth, she was not allowed to take care of her own child. She was not allowed to breastfeed her child, and this situation became worse when she decided to separate from her husband. Even though her child is now two years old, she has never met the child as her family's husband rejected her.

"The kid is now 3-4 years old. I'm glad he's healthy. My parents-in-law took care of him, but I am not allowed to meet him." (LI, Indramayu) "I'm not comfortable staying with my mother-inlaw. She is fierce and likes ordering me to do things." (LI, Indramayu)

This indicates that participants often lose their autonomy and must give in to their husbands and their husbands' families. Examples of loss of autonomy among women who married underage are told by three participants who since marriage could no longer meet their friends. They really missed the opportunity to get together with friends. Whenever they feel like meeting their friends, they need permission from their husbands. They also have no one else to take care of the children whenever they go out to meet friends. In the end the solution was to meet friends accomapnied by their husbands or by taking their children along. Two participants stated that since they got married, their husband would always come along wherever they go to. This makes them feel uncomfortable having lost their own freedom. The following are some of their complaints (Participants SI, NI, AM, and DM). Admitted that since marriage, their husbands have to go wherever they are going.

"...I want to go out, but who would take care of the child? I have a baby to take care of." (SI, Indramayu)

"...now I think I'm used to it, but I still feel envious towards my friends. They can still work, not like myself." (NI, Indramayu)

"...of course not, he must always come along.. maybe he's also envious..." (AM, Bekasi)

"Of course I'd like to hang out with my friends, but since I have a husband, this is how it is now. But I rarely meet my friends, or go out, usually I stay at home." (DM, Bekasi) 
Although not the majority, but three participants decided to separate or divorce their partners (Participants LI, SI, and HM). Other participants stated that they divorced because of unfair treatment, triggered by household quarrels. Since being married, participants and their husbands often times easily become jealous, emotional and possessive. Small things can trigger quarrels and disputes. One of the three participants admitted that what triggered their frequent quarrels was interference by her husband and his family, while one participant decided to separate due to economic matters.

Economic matters is often times the consequence of child marriages. As one participant shared her story that because of being young and unemployed, her husband was asked to assist at her parents' workshop. What he earned however was not enough to meet their daily household needs. The lack of good income often times triggered marital quarrels.

Another story related to economic matters came from one participants who stated that when she decided to marry her husband, he was working as a delivery person in one of the shops near their neighbourhood. Because they wanted to be independent, they decided to rent their own house. This had a strong impact on their own financial condition. When they were newly wed, they slept on the floor and this continued until they had their first child. Their newborn child even had to sleep on a cloth, because they could not afford buying a mattress.

Unstable economic conditions also made six of eight participants still lived with their parents or inlaws. They were still economically supported by their parents or in-laws. This was because their husbands did not earn enough money for a living. These are the complaints shared by participants AM, HM, and DM:

"We had no pressure. In the past, usually pressure was only from the school... but now... the pressure is lack of money... we feel uncomfortable because we still depended on our parents... I often regret this situation." (AM, Bekasi)

"Parents still assisted us, our parents still did the shopping for us... my husband's earnings was also used for household spending, or kept for savings. It's like that." (AM, Bekasi)

"...when it comes to money, he just wants anything, to but this or that, but he never cares about the expenses. He's like a kid buying anything he wants, for cigarettes and snacks. So when he comes home from fishing, he asks for many things." (HM, Bekasi)
"It's so unpleasant when it comes to lack of money." (DM, Bekasi)

Child marriage also has consequence on legal matters. Some participants were married according to religious law, but without recognized by the civil registry. Part of the reason was because they were underage by law. One participant had to falsely add up her age to be allowed to marry. Seven other participants needed a written statements from both parents to get married. One of the seven participants (Participants YJ) then registered her marriage after they reach their legal age.

"I raised my age to 17." (YJ, Jakarta)

"I did not use an ID card, because I did not have one." (YJ, Jakarta)

"I paid the KUA IDR800,000 to get a marriage certificate. I spend a total of IDR1.1 million to get the religious judge to marry us." (YJ, Jakarta)

The absence of civil registration of their marriages has a consequence in difficulties in obtaining birth certificates for their children. Two participants (LI and AM) had to register their children as children of their parents, in order to obtain birth certificates. This would cause more difficulties in the future for the participants and their children. In addition to the issue of difficulty in obtaining birth certificates, participants who marry in "siri" were in vulnerable positions, as they could easily be left by their husbands. Two participants (LI and HM), experienced this. When they had a fight, they were immediately abandoned by their husbands, who could just verbally say they are separated.

"The marriage was recognized by a religious clergy only, not by the civil registry." (SI, Indramayu) "Registry of my child to get a birth certificate was done by my in-laws, so the child was included in their family and recognized as their child, not mine." (LI, Indramayu)

"My child does not have a birth certificate. I only received a letter from a midwife, even though my child was not born with assistance of a midwife. I also had to pay IDR500,000 to get that letter from the midwife." (YJ, Jakarta)

Another consequence felt by participants was physical matters. Three participants (AM, YJ, and NI) experienced problems with their pregnancy. One participant (AM) lost both twin babies shortly after 
delivery, while two other participants (YJ and NI) had to give birth prematurely at eight months and five months. Unfortunately there was still no clear explanation of the cause, as the two participants did not fully understanding the matter itself.

"My child died as twins. At that time they was prematurely born, they were born not too long ago. In April. It's only 9 months now... premature 8 months... the first child did not die right away, but the second one died immediately. The first one lived for a week at the hospital before the child died." (AM, Bekasi)

"Premature 8 months, malnourished, $1.9 \mathrm{~kg}$. His appearance was thin, very boney." (YJ, Jakarta) "...the baby was born prematurely, so it was only five months when I was admitted to the hospital, the doctor said the baby had a weak heart. During pregnancy I had to frequently go to the hospital, the doctor said so." (NI, Indramayu)

\section{Discussion}

Previous studies related to child marriage indicate that the prevalence has decreased, but in fact field data show that there are child marriage practices still exist. According to Hanafi (2011), the absence of child marriage rates is due to the fact that child marriages are rarely recorded by the government agencies. Failure to register these child marriages are usually due to parents' or couples' reluctance to apply for dispensation at the court or legal representatives appointed by the parents.

Child marriages are caused by several factors, but along side with many social changes, most child marriages occur due to unhealthy and unsafe dating styles. According to Iustitiani and Ajisuksmo (2017), adolescents tend to be involved in risky behaviors related to sexual relations. Furthermore, many of these children are unable to refuse premarital sex when asked by their partners. The child then becomes vulnerable to unwanted pregnancies. By Indonesian norms, if one experiences unwanted pregnancy, then the only possible solution to that matter is to get married, regardless of age. Marriage is indirectly considered as a form of responsibility of both parties to avoid public disgrace. This eventually is the reason why child marriages still occur in Indonesia.

Gossiping and assumptions from the community are usually reasons for parents to marry their children. This is in accordance with Susenas data (2012, as cited in BPS, 2016) that adolescents choose to marry because of their parents wishes and stigma of unmarried adult woman, concerns about pregnancy, premarital sexual practices and poverty.

These conditions cannot be separated from education of the child's own education and education of parents and society. Desiyanti (2015) states that parents' and child's educational level are the causes of child marriages. Parsons et al. (2015) states that girls whose mothers have lower education levels are more likely to experience child marriage. Studies abroad also indicate that educational level is one facto causing child marriages (Stang \& Mambaya, 2011; Sah, Subedi, Shah, \& Jha, 2014). Low educational level will potentially make children marry at an early age, because they do not have sufficient knowledge about the consequences of child marriages.

Data indicates that those who marry underage tend to have dropped out of elementary and junior high school. Based on the analysis of education and marital status in the study conducted by BPS (2016), it is known that there is a relationship between low education and the tendency of child marriages. Analyses conducted using Susenas data of 2012 show that married girls have lower level of educational as compared to unmarried girls, especially at the secondary school level. Research conducted in Africa indicate that delaying the age of marriage will increase the rate of school participation and even reduce the dropout rate (Delprato, Akyeampong, Sabates, \& Hernandez-Fernandez, 2015). This suggests that education and child marriages are interconnected and affect each other.

On the other hand, lower education is also the consequence of child marriages. Data shows that those who are married young can no longer access education (Walker, 2012). Those who experience unwanted pregnancies and child marriage must withdraw from school. This is in contrast with the Joint Regulation of the Minister of Education and the Minister of Religious Affairs number 04/VI/PB/2011 and number MA/111/2011, on the registration and administrative selection process of prospective, nothing is mentioned about the prohibition of pregnant and married students to continue school. Law No.20 of 2003 on National Education System, Article 4 states that education is held in a democratic, fair and nondiscriminatory manner by upholding human rights, religious values, cultural values and national pluralism. In fact, it is also confirmed by the Minister of Education and Culture, M. Noah in response to a case of high school student who married her boyfriend in 
Tangerang in 2013, that schools have no right to prohibit pregnant and married students to continue school and take school exams (Detiknews, 2013).

Existing laws and regulations related to education have never prohibited pregnant and married children from continuing their education and schooling. Unfortunately many schools apply regional autonomy regulations and prohibit pregnant and married students to continue their schooling. There is no reason why schools should prohibit pregnant and married students to continue their studies. One reason for this could possibly be related to the school's reputation. Stang and Mambaya (2011) found that most schools do not allow students with unwanted pregnancies to continue schooling due to the fact that it will tarnish their reputation. But when one school was asked about this issue, the reasons put forward was more due to administrative matters. For example, if the school allows the pregnant student to continue her education until graduation, in the future when the student's child attends school, they will be questions about the child's year of birth and mother's year of graduation. This will have an impact to the school.

Economic factors are often time mentioned as a factor causing child marriages, but in fact this is the consequence of this matter. Hanafi (2011) found that education is not regarded as solution to life's problems. On the other hand, the solution to overcome financial needs is that they must marry. Other studies also revealed that parents tend to marry off their children to household and independent burdens (Stang \& Mambaya, 2011; Astuty, 2013; Sah et al., 2014). Judging from the data in the field, some couples still experience difficult economic conditions, and their parents still have to bear daily costs of the married child and her husband. BPS (2016) research data also shows that those who marry underage continue to live in hard conditions, and rarely area there any differences before and after their marriage. Child marriages causes the child to discontinue her education and so they have less opportunities to find a decent job. This explains why child marriages do not release them from financial problems, but instead economic problems remain after the get married (Parsons et al., 2015).

In addition to the education and financial consequences, child marriages also caused social, legal, health, and psychological consequences. From a legal point of view, raising or faking the child's age in order to get married is a violation of law. This is against government regulations governing marriage.
In addition, unregistered marriages will have consequences in difficulties to obtain birth certificates for their children.

The social and psychological consequence of underage marriage is the deprivation of freedom and autonomy. Field data indicates that after marriage, they become unable to meet friends because their husbands do not permit them or because they cannot leave their children for too long. Those who wish to have the freedom after marriage are in fact trapped into their own married life (Segal-Engelchin, Huss, \& Massry, 2016). Some studies found that the psychological impact of underage marriage is the tendency to have psychological disorders, deprived child well-being, and depression (Parsons et al., 2015; Walker, 2012; Ahmed, Khan, Alia, \& Noushad, 2013).

Violence, either physical, verbal or emotional, is also the consequence of underage marriage. Emotional instability makes young married couples tend to have more quarrels resulting in physical violence. Sardi (2016) explains that low knowledge of these underaged married couples makes them vulnerable to arguments and even divorce. It is also said that often time marital quarrels are also exacerbated because parents interfere. Yulianti (2010) adds that underage married couples tend to still be childish, selfish and self-indulgent. These attitudes are likely to trigger quarrels among underage couples.

Health matters can also be the consequences of those who marry underage, especially among girls. The risk of death is high especially among pregnant children. Yulianti (2010) states that women who are pregnant under 20 years of age tend to experience disorders in the womb. This is similar to data found in the field, that two participants in this study experienced disruption during their pregnancy process. Unfortunately, it is not clear whether this disorder is due to age or to other factors.

The various consequences of child marriage need serious attention, as these marriages tend to deprive children of their rights. This will eventually make married children to be in a vulnerable position where they lose their rights as a child. Therefore, there needs to be a serious attention to prevent child marriage.

\section{Limitations of the Research}

There are several limitations of this study, namely: (1) some participants tend to not be open enough because they were interviewed in public locations 
where family members are present; (2) participants' backgrounds tend to be homogeneous; and (3) the findings have not yet been compared to underaged husbands' point of view. It is suggested that further research look at the broader context, such as the point of view of boys, family, and society, and a more heterogenous background of participants.

\section{Conclusion}

The study finds that underlying factors causing child marriage, include the following: (1) unwanted pregnancy; (2) the influence of parents and the surrounding environment for fear of slander and unwanted things; (3) education; and (4) economy. The consequences of child marriage include: (1) dicontinuation of education; (2) economic instability; (3) violation of law, age falsification, unregistered marriage, difficulties in obtaining birth certificates; (4) deprivation of children's liberty and autonomy; (5) psychological problems; (6) violence; and (7) health problems especially in girls.

\section{References}

Ahmed, S., Khan, S., Alia, M., \& Noushad, S. (2013). Psychological impact evaluation of early marriages. International Journal of Endorsing Health Science Research, 1(2), 84-86.

Astuty, S. Y. (2013). Faktor-faktor penyebab terjadinya perkawinan usia muda di kalangan remaja di Desa Tembung Kecamatan Percut Sei Tuan Kabupaten Deli Serdang. Welfare StatE, 2(1), 1-10.

BPS. (Juli, 2016). Kemajuan yang tertunda: Analisis data perkawinan usia anak di Indonesia (Katalog: 4103015). Jakarta: Author.

Candraningrum, D., Dhewy, A., \& Pratiwi, A. M. (2016). Takut akan zina, pendidikan rendah, dan kemiskinan: Status anak perempuan dalam pernikahan anak di Sukabumi Jawa Barat. Jurnal Perempuan, 2l(1), 149-186.

Delprato, M., Akyeampong, K., Sabates, R., \& Hernandez-Fernandez, J. (2015). On the impact of early marriage on schooling outcomes in SubSaharan Africa and South West Asia. International Journal of Educational Development, 44, 42-55.

Desiyanti, I. W. (2015). Faktor-faktor yang berhubungan terhadap pernikahan dini Pada Pasangan Usia Subur di Kecamatan Mapanget Kota Manado. Jikmu, 5(2), 270-280.
Detiknews (4 April 2013). Mendikbud larang pemecatan siswi hamil, kepala sekolah jangan bandel. Retrieved from http://news.detik.com/berita/2211 243/mendikbud-larang-pemecatan-siswi-hamilkepala-sekolah-jangan-bandel

Hanafi, Y. (2011). Pengembangan modul pendidikan berorientasi penyadaran hukum untuk pencegahan perkawinan anak di bawah umur (child marriage) pada masyarakat subkultur Madura di daerah Tapal Kuda. Jurnal Studi Gender: Palastren, 4(2), 282-301.

Hartono, U. (2017, Desember). 30 Persen Pernikahan di Banjarnegara Dilakukan Anak di Bawah Umur. Retrieved from https://news.detik.com/jawateng ah/3775004/30-persen-pernikahan-di-banjarnega ra-dilakukan-anak-di-bawah-umur

Hidayangsih, P. S. (2014). Perilaku Berisiko dan Permasalahan Kesehatan Reproduksi Pada Remaja. Jurnal Kesehatan Reproduksi, 5(2), 1-10. Retrieved from http://ejournal.litbang.depkes.go. id/index.php/kespro/article/view/3886/3731

International Planned Parenthood Federation and The Forum on Marriage and the Rights of Women and Girls. (2006). Ending child marriage: A guide for global policy action. London: International Planned Parenthood Federation (IPPF). Retrieved from https://www.unfpa.org/publications/endingchild-marriage-guide-global-policy-action

Iustitiani, N. S. D., \& Ajisuksmo, C. R. P. (2017). Perilaku berisiko pada remaja di Kampung Nelayan (Studi kasus di desa Eretan Kulon, Indramayu). Prosiding SNaPP2017 Kesehatan, 3(1), 91-98.

Juniman, P. T. (2017, Februari). PBB Soroti Jumlah Pernikahan Anak di Indonesia. Retrieved from https://www.cnnindonesia.com/gaya-hidup/201 70207162847-277-191868/pbb-soroti-jumlahpernikahan-anak-di-indonesia

Lestary, H., \& Sugiharti. (2011). Perilaku Berisiko Remaja di Indonesia Menurut Survey Kesehatan Reproduksi Remaja Indonesia (SKRRI) Tahun 2007. Jurnal Kesehatan Reproduksi, 1(3), 136-144.

Naveed, S., \& Butt, K. M. (2015). Causes and consequences of child marriages in South Asia: Pakistan's perspective. South Asian Studies A Research Journal of South Asian Studies, 30(2), 161-175.

Parsons, J., Edmeades, J., Kes, A., Petroni, S., Sexton, M., \& Wodon, Q. (2015). Economic impacts of child marriage: A review of the literature. The Review of Faith \& International Affairs, 13(3), 12-22.

Peraturan Bersama antara Menteri Pendidikan dan Menteri Agama Nomor 04/VI/PB/2011. (2011). Jakarta: Author. 
Peraturan Bersama antara Menteri Pendidikan dan Menteri Agama Nomor MA/111/2011. (2011). Jakarta: Author

PSKK UGM \& Plan Internasional. (April, 2011). Laporan akhir: Perkawinan anak di Indonesia. Jakarta: Author.

Qibtiyah, M. (2014). Faktor yang mempengaruhi perkawinan muda perempuan. Jurnal Biometrika dan Kependudukan, 3(1), 50-58.

Rodgers, B. (2012). Child marriage in Ethiopia and its associated human rights violations. $U W \mathrm{Bo}-$ thell Policy Journal, 11-19. Retrieved from https:// uwbpolicyjournal.files.wordpress.com/2012/06/c hild-marriage-pdf-final.pdf

Sah, R. B., Subedi, L., Shah, U., \& Jha, N. (2014). Factors affecting Early Age Marriage in Morang District of Nepal. Scholars Journal of Applied Medical Sciences, 2(4C), 1320-1324

Sardi, B. (2016). Faktor-faktor pendorong pernikahan dini dan dampaknya di Desa Mahak Baru Kecamatan Sungai Boh Kabupaten Malinau. eJournal Sosiatri-Sosiologi, 4(3), 194-207.

Segal-Engelchin, D., Huss, E., \& Massry, N. (2016). The experience of early marriage: Perspectives of engaged and married Muslim women in Israel. Journal of Adolescent Research, 31(6), 725-749.

Stang, \& Mambaya, E. (2011). Faktor yang berhubungan dengan pernikahan dini di Kelurahan Pangli Kecamatan Sesean Kabupaten Toraja Utara. Jurnal MKMI, 7(1), 105-110.

Umemoto, S. H. (Ed). (March, 2001). Early marriage: Child spouses. Innocenti Digest No.7, Main issue. Florence: Innocenti Research Centre.

UNICEF. (2005). Early marriage; A harmful traditional practices: A statistical exploration. New York: Author.

Undang-undang Republik Indonesia No. 1 tentang Perkawinan Pasal 7 Ayat 1. (1979). Jakarta: Author.

Undang-undang Republik Indonesia No. 23 tentang Perlindungan Anak Pasal 4. (2002). Jakarta: Author.

Undang-undang Republik Indonesia No. 35 tentang Perubahan Undang-Undang Perlindungan Anak Pasal 26 Ayat 1c. (2014). Jakarta: Author.

Walker, J. A. (2012). Early marriage in Africa-Trends, harmful effects and interventions. African Journal of Reproductive Health, 16(2), 231-240.

Yulianti, R. (2010). Dampak yang ditimbulkan akibat perkawinan usia dini. Jurnal Pamator, 3(1), 1-5. 